CHAPTER 12

\title{
Aligning Macroeconomic Policies for Agricultural Transformation in Africa
}

Adamon N. Mukasa, Njuguna Ndung'u, and Abebe Shimeles 

griculture, even subsistence agriculture, does not operate in a closed environment and has important downstream and upstream sectoral

linkages. Most empirical studies have found that growth in agriculture is more effective in reducing poverty than growth in nonagricultural sectors (Irz et al. 2001; Christiaensen and Demery 2007; de Janvry and Sadoulet 2010). In fact, Shimeles (2015) has shown that the majority of individuals living in poverty in Africa, close to 54 percent, are active in the agricultural sector, followed by services, at around 32 percent, which is dominated by informal work arrangements, an offshoot of suppressed agricultural development. This means that agricultural development and transformation cannot be dissociated from the economic environment of a country or a region and that a conducive policy regime is therefore crucial to leverage the full potential of the agricultural sector (Díaz-Bonilla 2015).

Generally, the macroeconomic instruments governments deploy are diverse and seek to address short- and/or long-term concerns such as reducing uncertainty and overall risk in the national economic environment, promoting growth, and improving welfare and equity in income distribution. Although the underlying concerns in Africa regarding macroeconomic stability are never linked to the agricultural sector directly, the reliance on rainfed agriculture and the devastating consequences of periodic droughts and subsequent food supply constraints feed directly into a supply-side effect on domestic prices-inflationand disturb the trajectory of monetary policy programs. Durevall and Ndung'u (2001) show that the Kenyan government's control of maize prices, including the interdistrict maize movements from the 1970s to the 1990s, served as an instrument to contain inflation from the supply side.

This chapter discusses how accounting for macroeconomic perspectives when establishing agricultural policies can help African governments ensure that their agricultural sectors become productive, competitive, and lucrative across agricultural value chains. It presents the two-way linkages between agricultureled growth strategies and macroeconomic policies by focusing on price, fiscal, monetary, exchange rate, and trade policies. It also discusses the main constraints to effective agricultural policy and the options for integrating agricultural perspectives when developing macroeconomic policies.

\section{Urban and Anti-agricultural Bias of Macroeconomic Policies in Africa}

In many agriculture-dependent African countries, the performance of the agricultural sector determines the prevailing macroeconomic conditions, including economic growth, unemployment, balance-of-payments conditions, and fiscal balances (Díaz-Bonilla 2015). However, in many countries, farm earnings have often been depressed by macroeconomic policies with pro-urban and antiagricultural and anti-trade biases. Despite significant strides in reducing those policy biases in recent decades, distortions to agricultural incentives remain widespread in most African countries.

In the 1960s and 1970s, many African countries implemented pro-urban, anti-agricultural, and anti-trade macroeconomic policies at the expense of farm households (Krueger, Schiff, and Valdés 1988, 1991; Thiele 2004; Anderson and Masters 2009). This urban bias was created by direct interventions in agricultural markets via a heavy tax burden on agriculture and by indirect interventions through overvalued exchange rates and import substitution policies (Krueger, Schiff, and Valdés 1992; Wiebelt et al. 1992).

A large portion of postindependence African governments' expenditures has been focused on developing urban economies and infrastructure. For instance, Botswana, a country that has experienced sustained positive rates of economic growth over the greater part of its postindependence period, has been committing nearly 85 percent of its development funds toward the development of urban social and physical infrastructure. This is despite economists' pre-independence recommendations to prioritize agriculture-based development growth. Even when later development plans involving agriculture were initiated, they tended to have an urban-elite bias favoring large commercial farms rather than smallholder farmers.

Further compounding the problem of macroeconomic policies characterized by urban bias is the discrimination in pricing policies of most African countries. Food prices have frequently been subjected to distortions through direct and indirect price interventions to address urban food needs and keep urban-economy wages low. One possible measure of the impact of price interventions in agricultural output markets is the nominal rate of assistance (NRA), defined as "the percentage by which government policies have raised gross returns to farmers above what they would have been without the government's 
intervention" (Anderson and Masters 2009, 11). Negative values indicate greater taxation on the agricultural sector, while positive values reflect supports to the sector. In Africa, the NRA has been negative since the waves of independence in the 1960s. In the 1960s, Africa's NRA values were among the highest in the world, with a tax equivalent of about 10.3 percent of the value of total agricultural production. Only Asia (excluding Japan) surpassed the continent, with an estimated NRA of -25.6 percent. However, while the other regions managed to gradually shift from heavily taxing the agricultural sector to supporting the sector beginning in the 1990s, Africa has remained the only region that continues to tax agriculture-though it does so at continuously lower rates, moving from about -6.2 percent over the period 1990-1999 to -4.3 percent in the 2000s (Anderson and Masters 2013). Since the 2010s, likely due to country commitments under the Comprehensive Africa Agriculture Development Programme (CAADP) and the Malabo Declaration of 2014, NRAs for agricultural products have become positive, reaching on average 19.2 percent (MAFAP 2018a).

Evidence of anti-agricultural policies in Africa also comes out clearly when the NRA values of agricultural products are compared with those of nonagricultural products. The underlying indicator called the relative rate of assistance (RRA) therefore indicates the extent to which African countries have supported their agricultural sector relative to nonagricultural sectors. A negative RRA signals an anti-agricultural bias, while a positive value suggests proagricultural bias. If both agricultural and nonagricultural sectors are equally assisted by a country's macroeconomic policies, then the RRA is zero. Between 1960 and 2010, macroeconomic policies in African countries favored nonagricultural sectors more than the agricultural sector, with the NRA almost always negative and lower than the NRA for tradable nonagricultural sectors. And despite the CAADP commitments and national agricultural development strategies, policy supports to the agricultural sector have remained insufficient to completely suppress the observed anti-agricultural bias in Africa.

The above regional averages, however, hide important heterogeneity across countries and agricultural products. A visual inspection of NRAs across 19 African countries with available data is provided in Figure 12.1. It shows a significant reduction in taxation of farmers in countries such as Côte d'Ivoire, Ethiopia, Senegal, and Tanzania from 1960 to 1999 (pre-2000 period) and 2000 to 2017 (post-2000 period). It also identifies countries transitioning from taxing to supporting agriculture, such as Mozambique and Uganda, as well as countries transitioning from support to taxation of agriculture, such as Kenya, Nigeria, and South Africa. In countries such as Burkina Faso, Kenya, Malawi, and Mali, agricultural NRAs have been on average positive since the 2000s. Overall, empirical evidence suggests that agricultural NRAs and RRAs tend to be positively and significantly correlated with per capita gross domestic product (GDP) in Africa (Figure 12.2). Variations in NRA levels among agricultural products are shown in Figure 12.3 and suggest that commodities such as rice, cotton, and maize receive the highest level of agricultural assistance and support from African governments, whereas cash crops such as tea, cashew, and sugar (since 2010) are heavily taxed.

\section{FIGURE 12.1-TRENDS IN THE NOMINAL RATE OF ASSISTANCE TO AGRICULTURE IN SELECTED AFRICAN COUNTRIES}

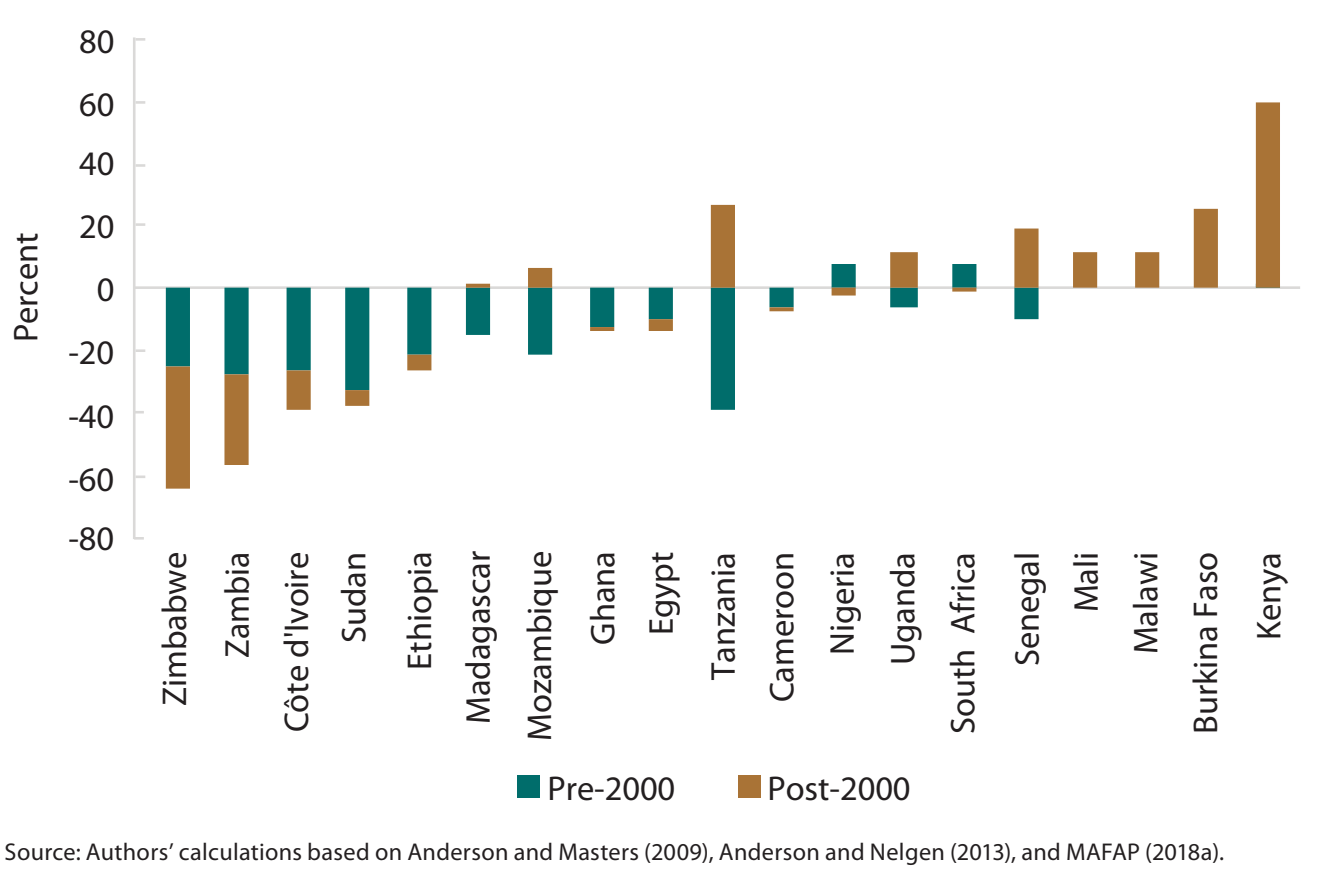




\section{FIGURE 12.2-RELATIONSHIP BETWEEN AGRICULTURAL NOMINAL RATES OF ASSISTANCE AND RELATIVE RATES OF ASSISTANCE AND REAL GDP PER CAPITA BETWEEN 1960 AND 2010}

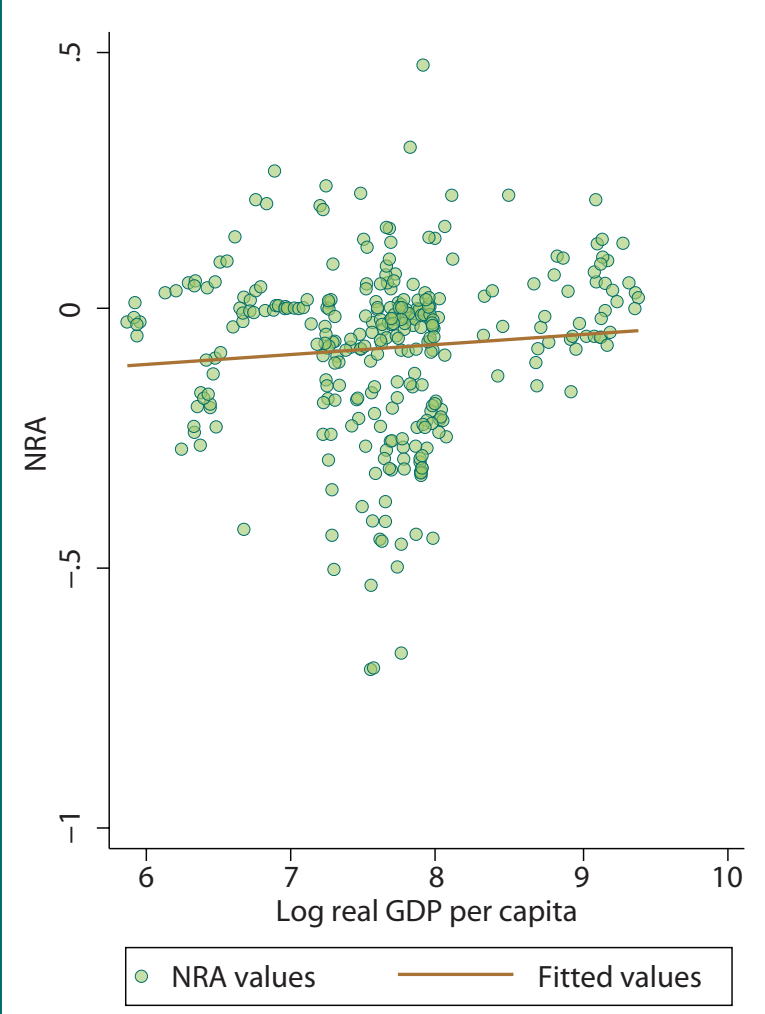

Slope $=0.02$, Std. error $=0.00, F-$ stat $=2.39$

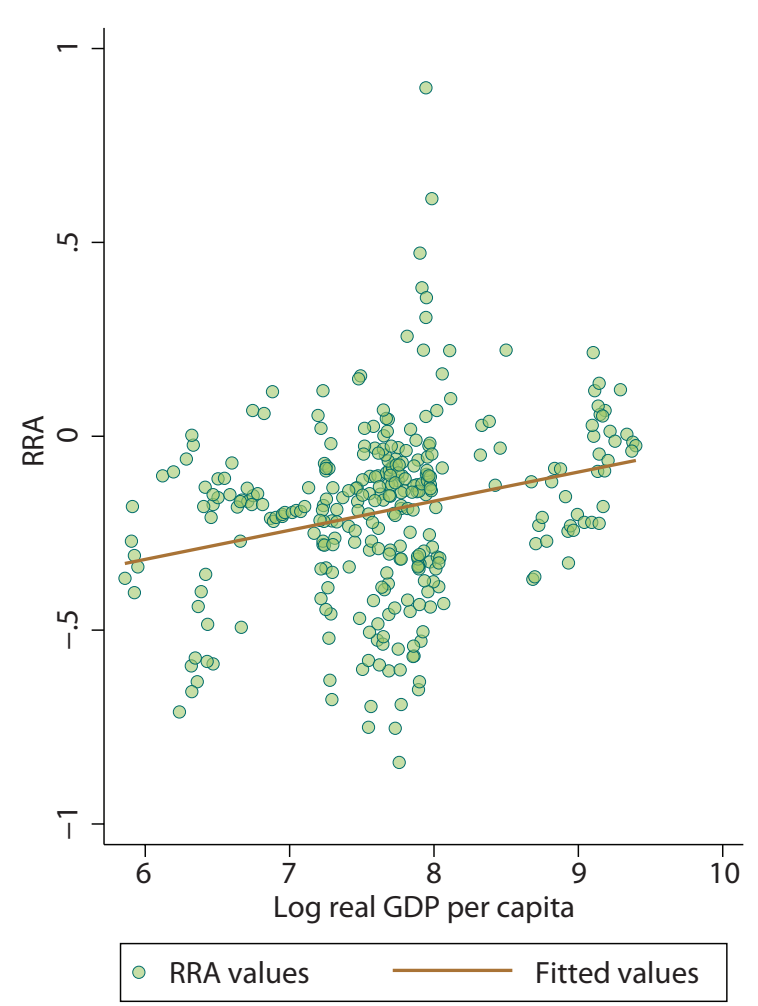

Slope $=0.08$, Std. error $=0.00$, F-stat $=20.47$

Source: Authors' calculations based on Anderson and Nelgen (2013) and World Bank (2020).

Note: $\mathrm{NRA}=$ nominal rate of assistance; $\mathrm{RRA}=$ relative rate of assistance.

The above analysis suggests that in many African countries, macroeconomic and agricultural policies are disconnected, a stark contrast with the experiences of countries that have managed to achieve both agricultural and industrial development. African countries' macroeconomic policies have not only been disconnected from agricultural needs and agrarian development; they have actively punished the underdeveloped agricultural sector through various forms of taxation and indirect transfers to the urban economy. Fuel subsidies and subsidies on increasingly popular consumer goods such as packaged staples of maize, rice, and wheat work in the interests of urban residents but are meaningless for the economic welfare of smallholder farmers in rural areas. In addition, monetary and financial policies promoting lending to micro- and small businesses and low-income groups have mostly tended to exclude rural smallholder farmers. However, with renewed interest in the need to promote agriculture in various African countries, financial policies providing for credit guarantees to smallholder farmers have emerged in countries such as Kenya and Rwanda.

\section{State of Macroeconomic Policy Targeting the Agricultural Sector in Africa}

Anti-agriculture-industry bias can be traced back to the postcolonial socioeconomic and political context within which macroeconomic policies promoting the urgently needed economic growth were embedded. Schiff and Valdés (1992) provide details of the socioeconomic and political context, in which former colonies wanted to free themselves from their past role as economically dependent and peripheral raw commodities suppliers to former colonizers and from the international economic order in which the real exchange rate was seen to favor imported industrial products over agricultural exports. Many African country leaders also had the general feeling that they needed to transform their economies from raw material outposts to economies that could manufacture products that were at that time predominantly imported. Agriculture was viewed as backward, traditional, less responsive to market signals, and having limited links to other sectors of 
FIGURE 12.3-TRENDS IN THE NOMINAL RATE OF ASSISTANCE TO AGRICULTURE IN SELECTED AFRICAN COUNTRIES

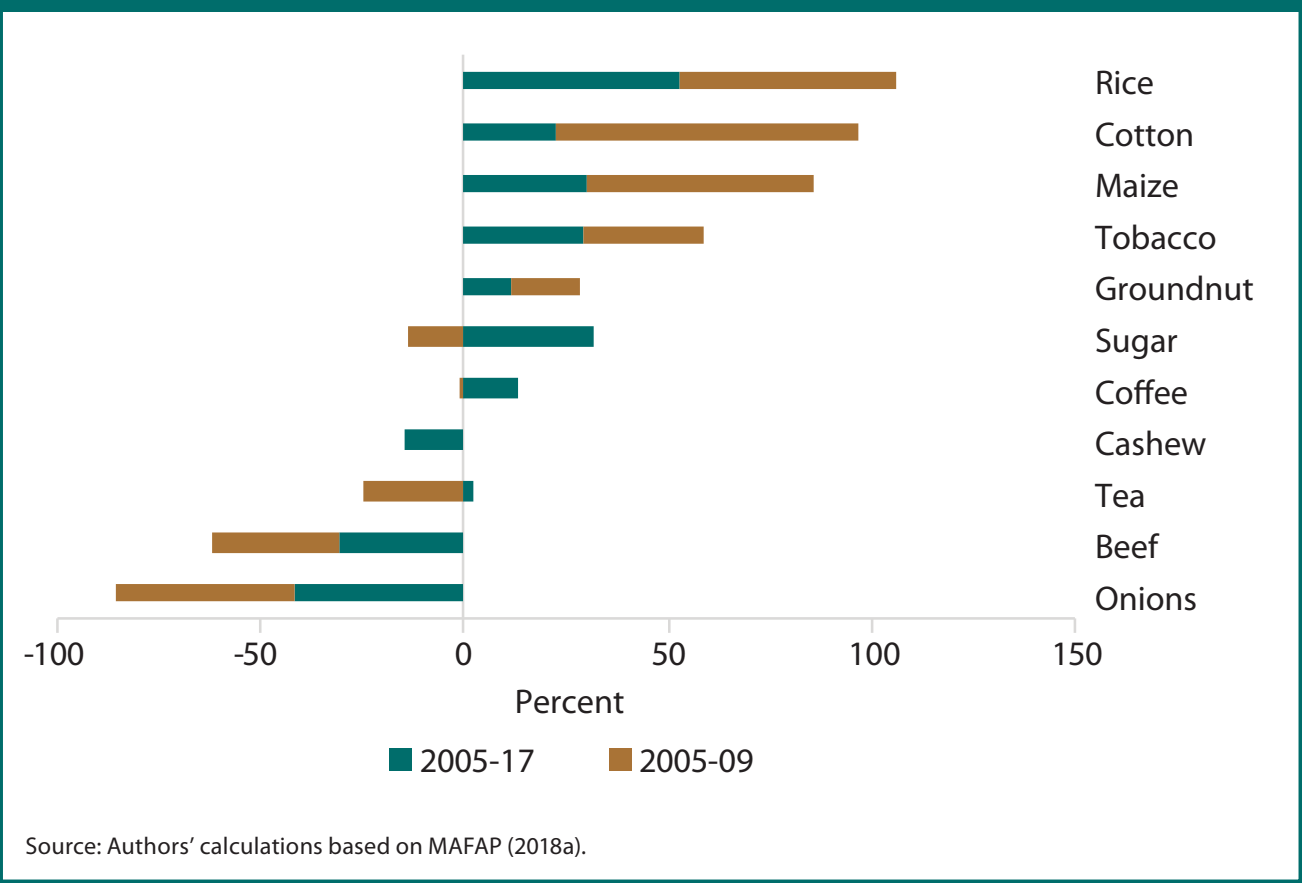

the economy. The main issue of allocation of limited investment resources was therefore settled decidedly in favor of industry over agriculture, thus ushering in import substitution policies. The boom-and-bust cycles that agricultural commodities undergo in international markets also provided a reason for macroeconomic planners to shun externally oriented sources of revenue. Agricultural-sector-specific policies such as tariffs, price controls, input and credit subsidies, quantitative restrictions, government expenditures, and taxes distorted the agricultural incentives for many farmers.

\section{Fiscal Policy}

High taxation rates have characterized African agricultural exports for decadescontinuing even to current times, though there has been a marked reduction in the rate of taxation. Export crops such as cocoa, tea, and coffee are taxed as a major source of foreign exchange and revenue, which is a requisite for dealing with fiscal deficits. Essentially, the agricultural sector has been used as a revenue source by the various African governments to subsidize the protected industrial sector. At the same time, the domestic producers of importcompeting staples such as maize and rice are heavily subsidized, with producer prices well above global prices, though this has not resulted in enough increased productivity to meet food self-sufficiency goals in many African countries. Nontradable agricultural products such as plantains, sweet potatoes, and cassava are hardly supported by governments.

\section{Trade Policy}

Trade policies directly impact agricultural productivity and growth. Trade liberalization policies can increase agricultural productivity by creating competitive export and import opportunities, which are generally efficiency enhancing. Usually, African governments use trade policies to meet one or more specific economic and social priorities such as food security, price stability, lower prices and increased availability of staple food items, foreign exchange to enable fiscal equilibrium, and economic sectoral development. Trade policies, though heavily influenced by the national economic context, sectoral composition of growth, food security concerns, fiscal equilibrium concerns, and employment creation, can have both short- and long-term price effects and implications for access, availability, stability, and utilization aspects of food security (FAO 2016). Trade policy in Africa is becoming more regionalized while progressing toward a more liberalized regime, though protectionism still persists due to tariff and nontariff measures such as subsidies on cereals and grains during cyclical food crises. African governments' interventionist policies in agricultural trade have their root in past institutional arrangements in which government marketing boards controlled the marketing of agricultural products and inputs. Swinnen, Vandeplas, and Maertens (2010) and Kherallah et al. (2002) have noted that in countries in the East African and southern African regions these institutions were more engaged in the production and marketing of staples, while their West African counterparts focused interventions on the supply chains of export crops.

One way to capture the nature of trade policy toward the agricultural sector is by looking at the trade bias index (TBI) using NRAs for exportable agricultural products and import-competing products (Anderson and Masters 2009). The 
$\mathrm{TBI}^{1}$ evaluates the extent to which a country's policy regime creates an anti-trade bias within its agricultural sector. The more negative the index, the larger the agricultural anti-trade bias and the larger the gap between support to importcompeting agricultural subsectors and assistance to exportable agricultural sub-industries. Available data suggest that agricultural anti-trade bias has been persistent in Africa, worsening between 1960 and the late 1980s before improving since the 1990s.

The proliferation of tariff and nontariff barriers to agricultural trade deserves attention when considering agricultural trade policy in the region. These tariffs change the relative prices of commodities (outputs, inputs, machinery, or equipment). Nontariff barriers translate into lost agricultural earnings due to missed trade opportunities, in addition to the loss to producers who cannot capture market prices in informal trade taking place across borders as a way to circumvent complex and numerous customs rules. Informal market exchanges tend to be more costly to producers, and in this instance smallholder farmers are often at the mercy of middlemen who are the key movers in such informal markets. Kalaba (2012) noted, for instance, that the number of nontariff measures between Malawi, Mozambique, and Zambia rose from 400 to 1,400 between 2000 and 2010, implying an average increase of 100 nontariff measures on agricultural products per year. In the case of the East African region, Karugia et al. (2011) found that nontariff barriers account for as much as 35 percent of the cost of maize transfers, thus eliminating a large share of value that could have been captured by the producers. Nevertheless, trade in staple food items is becoming increasingly important for many African countries, considering the lack of domestic capacity to meet growing demand under compelling domestic pressures for food security and self-sufficiency. The largest increase in African food imports is occurring in the grain and meat categories, a clear indication that African countries' agricultural trade is defined primarily by deficits in the domestic supply of staple items such as maize, rice, and wheat.

The nominal rate of protection (NRP) can be used to compute the impact of tariffs on agricultural prices. The NRP measures the extent to which a set of agricultural trade policies affects the market price of a commodity. It is calculated as the percentage price difference between the farmgate price received by producers and an undistorted reference price at the farmgate level. A negative NRP suggests that tariff barriers distort the domestic farmgate prices received by producers. The graphs in Figure 12.4 show the trends in NRPs for four key commodities (maize, rice, cassava, and sorghum) in a sample of African countries using available data over the subperiods 2005-2009 and 2010-2017. For maize, NRPs are positive in countries such as Burkina Faso, Burundi, Kenya, Mozambique, and Uganda throughout the surveyed period. In Kenya, for instance, the increasing trend in NRPs-from 27.3 percent in 2005-2009 to 52.7 percent in 2010-2017-could be explained by adverse weather conditions that negatively impacted maize production and led the National Cereals and Produce Board to intervene by increasing domestic prices (Apell, Nelgen, and Anderson 2019). With Kenya being the main export market for Ugandan maize, price distortions in the former country influence maize NRPs in the latter. Maize NRPs in Tanzania have benefited from a more liberalized market environment as the country has lifted maize export bans imposed in the past (MAFAP 2018b).

In almost all the countries under analysis, rice NRPs are positive over the period covered. Because rice is a strategic crop for food security in Africa, many countries have implemented policies aimed at supporting rice production and consumption. They have also put in place national rice development strategies as an import substitution policy to ensure self-sufficiency in rice production and support rice farmers. Interventions have included increased direct budget allocations to the rice sector and the imposition of high tariff rates for imported rice.

The same pattern of NRPs can be observed for cassava, especially since 2010, as African countries have implemented national cassava sector strategies to boost the contribution of the sector to economic development, improved food security, and poverty reduction. For sorghum, however, NRPs are globally negative,

implying distortionary effects of agricultural tariffs on domestic farmgate prices. This could reflect an antiproducer bias of policy support to the sector, which is likely considered less strategic than crops such as maize, rice, cassava, or wheat.

\section{Monetary Policy}

Monetary policy directly influences inflation, employment, exchange rates, and interest rates in an economy. Monetary and fiscal policies are used together as twin policy tools to bring about the desired macroeconomic impact. For instance, an increase in the supply of money that exceeds the actual growth in aggregate

1 The trade bias index is computed as $T B I=\left[\left(1+N R A a g_{X} / 100\right) /\left(1+N R A a g_{M} / 100\right)-1\right]$, where $N R A a g_{X}$ and $N R A a g_{M}$ are NRA values for exportable and import-competing agricultural subsectors. 


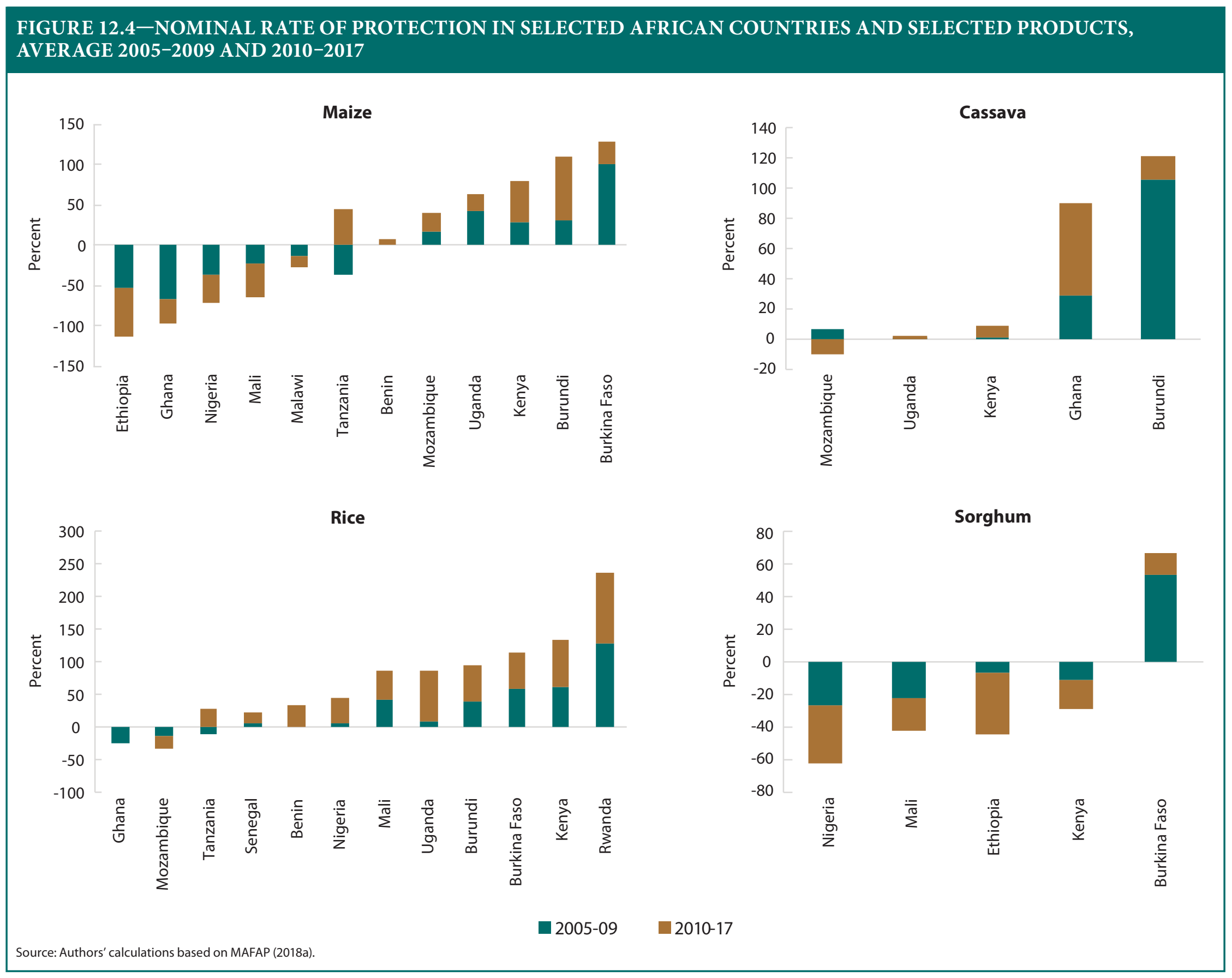


goods and services will trigger inflationary pressure, which will impact all economic sectors, including agriculture. Agricultural price levels and their stability over time are therefore directly affected, positively or negatively, by monetary policies. Interest rates and financial policy impact the availability and cost of lending to the agricultural sector (Figure 12.5). Lack of credit and financial services for smallholder farmers, a longtime market failure in the African agricultural sector, remains one of the most critical problems.

The trends of the relative prices of agricultural and nonagricultural products or overall products can also provide useful insights on how the macroeconomic environment can affect the agricultural sector differently from other economic sectors. For instance, if all prices within a country are rising at the same rate, one would not expect agriculture to suffer more than any other sector. In Figure 12.6, we report the evolution of agricultural goods' prices and overall prices in Africa between 2000 and 2018. As can be seen, over the entire period, the inflation rates for agricultural products have been higher than the average inflation rates for all

FIGURE 12.5-TRENDS IN ANNUAL INFLATION RATES AND REAL INTEREST RATES IN AFRICA, 1980-2018

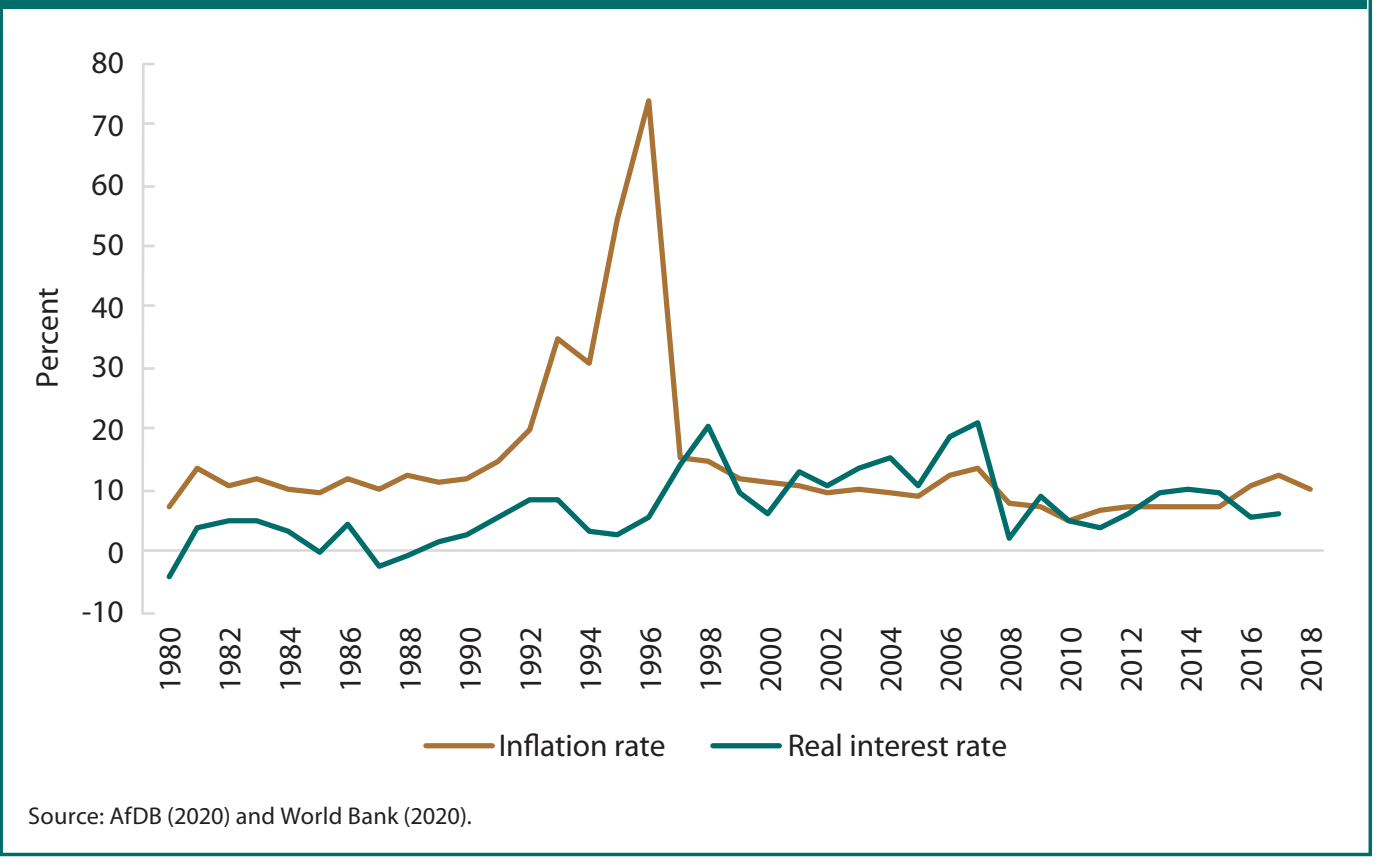

products, suggesting that agricultural goods' prices have been increasing much faster than those of average goods in Africa, perhaps as a result of higher imports of food products-due to insufficient domestic production-and import taxes. For net buyers such as the vast majority of Africa's subsistence farmers, higher agricultural prices might exacerbate food security and increase the risk of falling into poverty.

Foreign exchange rate policies are another important monetary policy component with a significant and direct bearing on the price of agricultural inputs and outputs. An appreciating national currency can weaken the price competitiveness of agricultural exports while lowering the price of imports. The direct price implications can be more obvious when an agricultural product is traded internationally, so the imports or exports of agricultural products are subject to the prevailing exchange rate of a national currency vis-à-vis other hard currencies used in direct trade, and those of competitors for the traded item. An undervalued exchange rate works in favor of increased exports due to international price competitiveness. In essence, the foreign exchange rate is one of the macroeconomic variables that directly impact the international competitiveness and balance-of-payments situation of any national economy (Figure 12.7). At the same time, it is worth noting the important role agricultural commodities play as foreign exchange earners in many African countries, in addition to other macroeconomic priorities of the various countries. Even though there is heterogeneity in African countries' use of exchange rates to influence macroeconomic outcomes, including in the agricultural sector, the common denominator is that a majority of African countries liberalized foreign exchange during the 1990s and continued on the same path in the next decade. Liberalized exchange rates are pro-trade, which benefits agricultural producers even though the overall benefits depend on a host of factors such as the import intensity of inputs and any positive externalities generated by agricultural exports.

\section{Monetary Implications of Anti-agricultural Bias in Africa}

The existence of notable distortions to agricultural incentives in Africa has significant monetary implications, as these distortions impose a major tax burden on African farmers, thereby reducing 
FIGURE 12.6-TRENDS IN ANNUAL INFLATION RATES OF AGRICULTURAL VERSUS ALL PRODUCTS IN AFRICA, 2000-2018

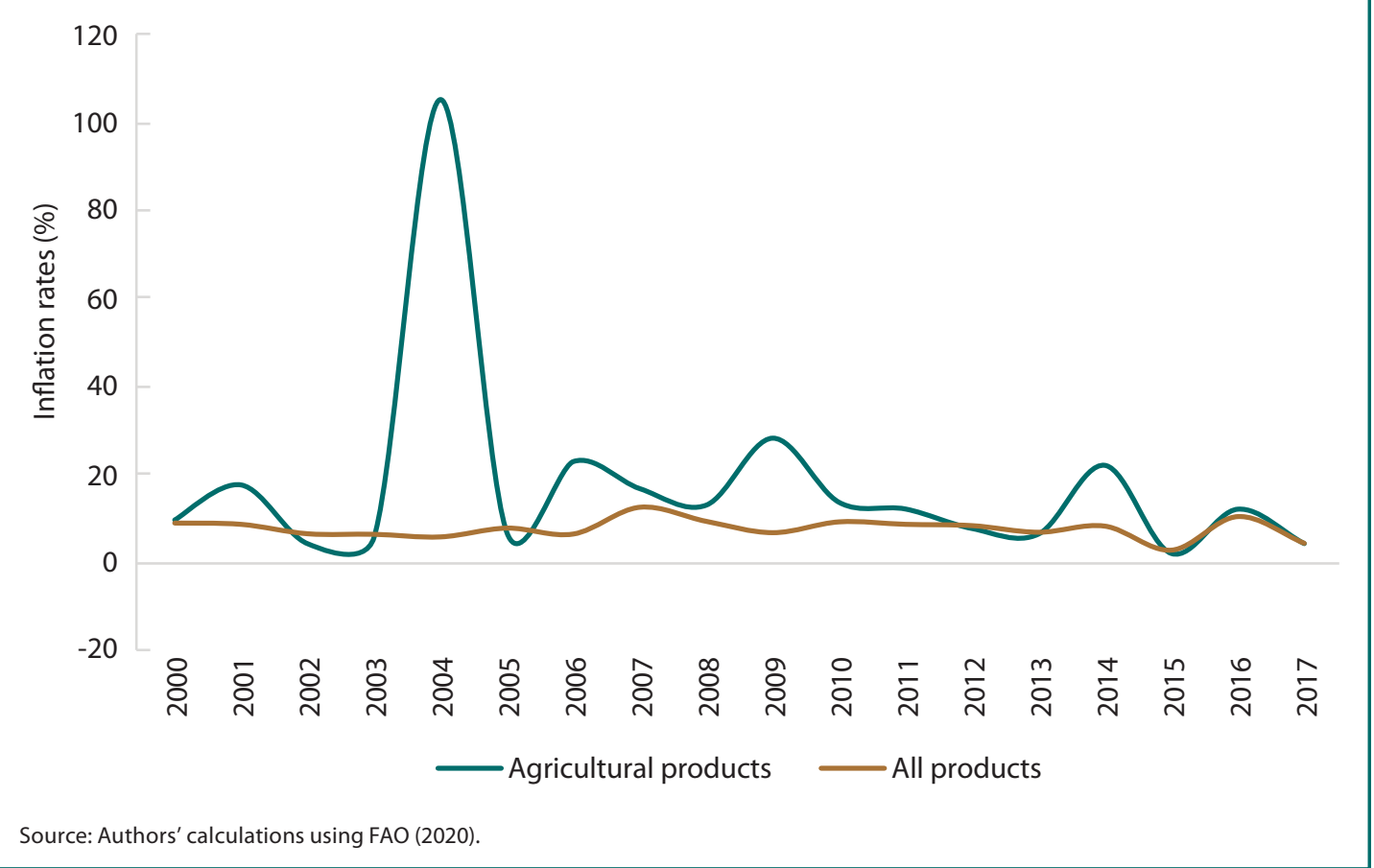

the attractiveness of agriculture and undermining its transformation into a lucrative sector. While other regions of the world have continuously supported their farmers with substantial agricultural subsidies, African farmers are still heavily taxed as a result of an anti-agricultural bias. Available data show that the total value of annual transfers from farmers (or tax imposed on farmers) has increased from an average of US $\$ 3.9$ billion in constant 2000 US dollars in the 1960s to a peak of US $\$ 10.9$ billion in the 1970s, before gradually declining afterward. Evaluated in terms of workers engaged in agriculture, the burden of agricultural taxation is such that, in Africa as a whole, each farmer paid a gross annual tax amounting on average to US\$66.50 in constant 2000 US dollars between 1960 and 2010. In 2010, the most recent year with available data, the burden of taxation on Africa's agricultural sector averaged US $\$ 31.8$ billion, or US $\$ 238.70$ per farmer (Anderson and Nelgen 2013). However, compared to the peak in the 1970s, African farmers are currently taxed less, due in part to the reductions in taxation of farmers that occurred in many African countries in an effort to stimulate the performance of the sector and attract private sector actors and foreign investors.

At the country level, the burden of agricultural taxation is the largest for farmers in Côte d'Ivoire, Sudan, and Zimbabwe, while agricultural transfers to farmers (subsidies) are important in South Africa, Egypt, and Nigeria, Africa's three largest economies. In Côte d'Ivoire, for instance, each person engaged in agriculture was taxed on average US $\$ 818.90$ per year between 2000 and 2009 due to high taxation on the country's major export cash crops (cocoa, coffee, and cotton). Agricultural taxation has since decreased in the country as Ivorian authorities have established agricultural sector policies aimed at supporting major cash crops and increasing the competitiveness of domestic markets. Hence, taxes on exports of cocoa butter have been reduced from 14.6 percent to 11 percent, while taxes on cocoa mass have dropped to 13.2 percent from 14.6 percent. South Africa, in contrast, has supported its agricultural sector through a series of policy instruments targeted at farmers, including not only direct subsidies but also many regulatory instruments aimed at increasing health, safety, and the protection of natural agricultural resources (Kristen, Edwards, and Vink 2009).

\section{Constraints to Effective Macroeconomic Policy Impact on Africa's Agriculture}

\section{Supply-Side Constraints}

Supply-side constraints to macroeconomic policies and efforts aimed at making agriculture a lucrative business are diverse. There is a good deal of heterogeneity among African countries with regard to the level of severity of the supply-side constraints. The most salient constraints are lack of credit, with an average of only 
FIGURE 12.7-TRENDS IN THE MEAN REAL EFFECTIVE EXCHANGE RATE INDEX IN AFRICA, 1980-2018

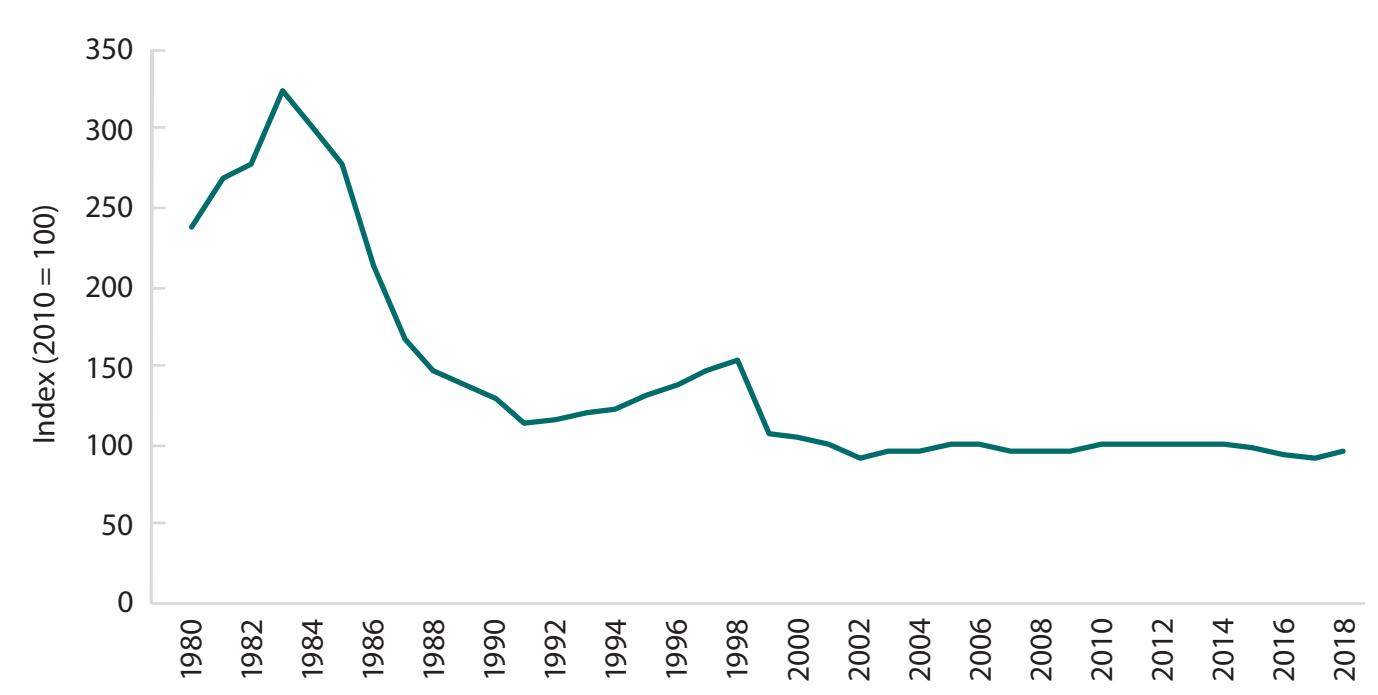

Source: Calculated by authors based on World Bank (2020)

6 percent of smallholder farmers able to secure credit to purchase inputs, the main one being fertilizer. There is little variation among countries in access to and use of credit to buy agricultural inputs by smallholder farmers-Malawi is at 5 percent, Nigeria 3 percent, Tanzania 11 percent, and Uganda 6 percent (Adjognon, Liverpool-Tasie, and Reardon 2018). Lack of access to technologies and infrastructure, relatively high input prices, lack of institutional capacity, and inadequate knowledge are also widespread constraints faced by smallholder farmers across African countries. Furthermore, the poor quality or lack of infrastructure such as roads, electricity, and storage facilities in the rural parts of African countries where agricultural activity takes place is a major constraint. The infrastructure deficit has adverse impacts such as increased costs of market access, increased information asymmetry between markets and producers, and postharvest loss. In addition, the negligible spending on and neglect of research and development (R\&D) and agricultural extension work across the continent undermines the knowledge base of smallholder farmers and the rate of adoption of new methods and inputs.

\section{External Sources of Funding and Volatility}

The lack of financial resources for investment in agricultural production and supporting activities is exhibited primarily in the underdeveloped agricultural investment market in most African countries. Agriculture receives a negligible share of foreign direct investment compared to sectors such as natural resource extraction. At the governmental level, insufficient budget allocations impede the implementation of sound macroeconomic policies and general agricultural development. Funding from external sources for agricultural development in Africa has reflected a history of fluctuating resource commitments from a loose grouping of actors ranging from charitable foundations to multilateral agencies. The 1970s and 1980s were marked by decreasing donor spending on agriculture in Africa, but from 2008 onward there have been increased commitments, specifically funds marked for regional scientific research (Pingali, Spielman, and Zaidi 2016). Recent increased public spending on R\&D is a significant positive development, though the spending is still perhaps not enough to make a serious impact. In the face of shortfalls in national governments' spending on agricultural R\&D, external sources such international charitable foundations and nongovernmental organizations have become critical to the funding of African agricultural development. The CAADP framework may be a good catalyst to boost external funding, as it provides for a relatively coordinated approach-including for handling external partnerships-to developing the agricultural sector in Africa.

\section{Demand-Side Constraints}

The African population is currently 1.3 billion persons and is still quite young and projected to keep growing, which points to healthy demand conditions for food production. However, healthy growth of the agricultural sector requires a sound and stable macroeconomic environment characterized by low inflation 
and rising incomes for agricultural producers and consumers. Low incomes and price inflation negatively impact demand conditions. It is notable that a rise in agricultural prices needs to be matched by rising domestic incomes to keep demand conditions stable. However, as incomes increase and the middleincome demographic expands, tastes also change, particularly among urban populations. Changes in tastes can be a challenge to local staple food production and relative output prices.

Overall, African demand for food remains very high, as can be understood from the rising imports. Increases in agricultural production within African countries could in the long run partially displace these imports, though international competition remains an external threat factor. However, the development of new infrastructure and improvement of existing infrastructure linking rural agricultural production zones to markets could help to eliminate high marketing costs as a demand-side constraint. In addition, nontariff measures that limit intra-African trade are a constraint on the demand side, and when the rules push trade into informal market channels, smallholder farmers face higher costs and fewer benefits.

\section{Looming External Debt}

One of the consequences of macroeconomic imbalances in many African countries is the accumulation of debt, particularly external debt, which, if unchecked, could lead to reduced investment in agriculture. In the last four decades, external debt typically followed a pattern of escalation due either to procyclical behavior of government spending or to exogenous shocks, such as the deterioration of terms of trade, to which most African economies exhibit frequent vulnerabilities.

As Figure 12.8 depicts, Africa's external debt as a share of GDP accelerated after the 1970s in the wake of the oil price crisis that sent shockwaves across the globe. As most African economies shrank, deficits mounted, and debt arrears accumulated, most countries faced debt crises and debt overhang, eventually leading to a massive debt-relief effort under the Heavily Indebted Poor Countries Initiative with a condition of implementing what were popularly known as structural adjustment programs. As a result, external debt began to decline significantly in the late 1990s. During that period, African economies also enjoyed significant economic revival, buoyed by improvements in the terms of trade, particularly an unprecedented rise in the prices of export commodities that lasted for more than a decade. Economies were significantly bolstered by increases in foreign direct investment and remittances, accelerating the pace of urbanization and the emergence of a middle class with increasing purchasing power-which also accelerated the importation of processed high-value agricultural products. However, external debt rose again after 2010 as capital markets began opening up for African

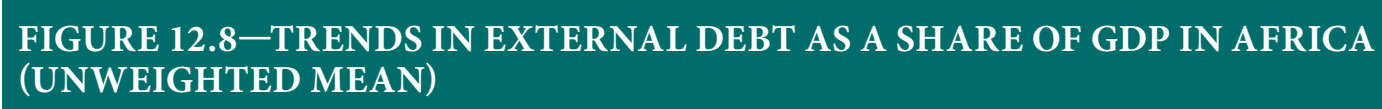
(UNWEIGHTED MEAN)

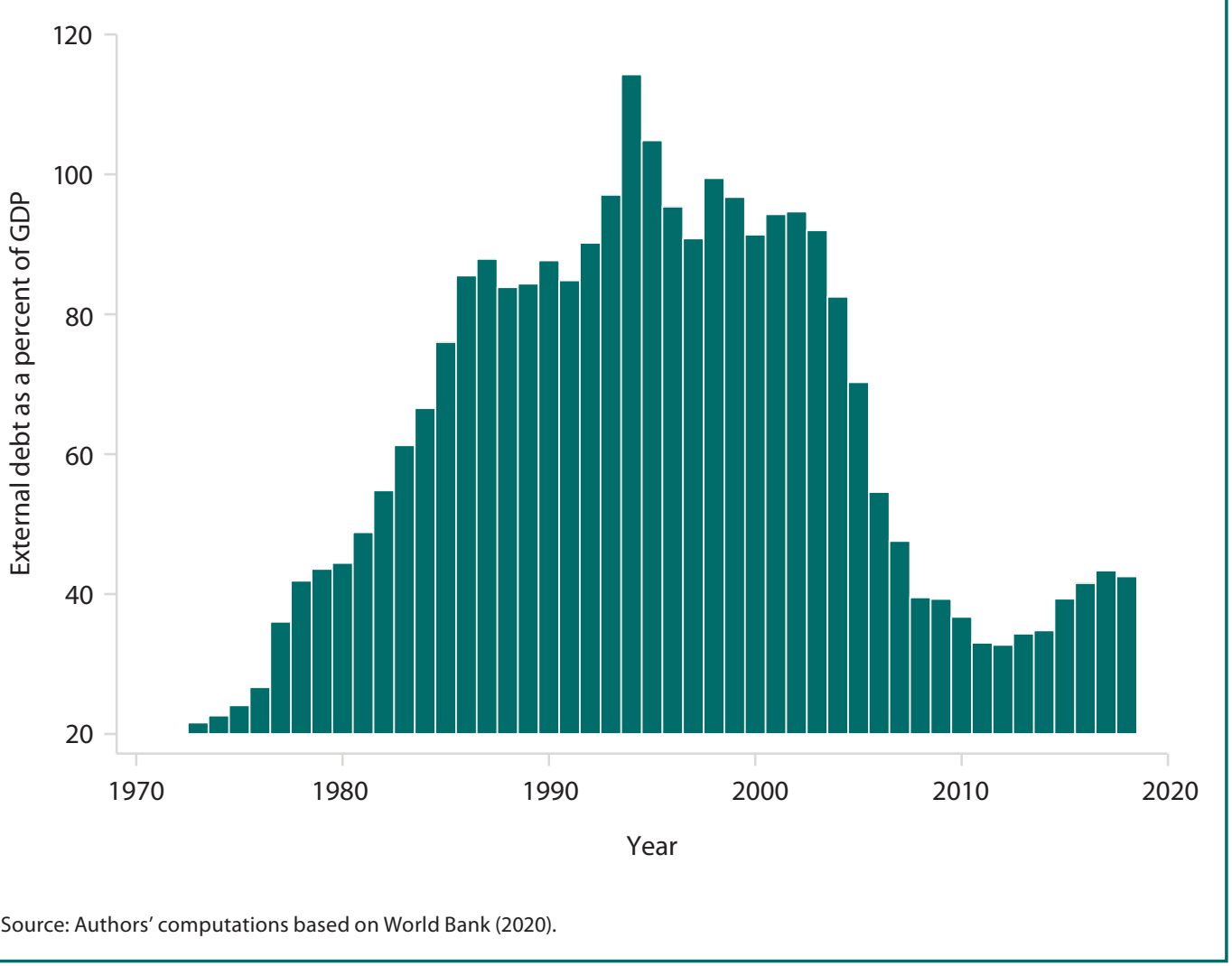


dollar- or euro-denominated sovereign bonds in the wake of the 2008/2009 global financial crisis, offering many governments access to borrowing opportunities without conditionalities, albeit at a higher rate of interest. The end of the commodity price super cycle hit the budgets of many African governments as debt service increased. According to the International Monetary Fund (IMF 2020), as many as 8 African countries were in debt distress and about 16 at high risk of debt distress, indicating that the trend, if continued, could lead to a significant macroeconomic setback for many African countries.

As shown in Figure 12.9, the ratio of debt service to exports, a key indicator of debt burden and potential for debt sustainability, began rising in Africa in 2010, following the trend in the debt-to-GDP ratio. The increase sped up after the collapse of commodity prices in 2013, reaching an average of nearly 10 percent of export earnings used to service debt. However, the average hides significant variation across countries. The situation is dire in Mauritius (56 percent), Angola (26 percent), Mozambique (26 percent), and Ethiopia (22 percent), as well as Egypt, Côte d'Ivoire, and other countries that have exceeded 15 percent, which is often considered the maximum share of its export earnings that a country should be devoting to service debt. The question is, what are the potential implications of rising debt for the agricultural sector?

One potential problem rising external debt may cause is the diminishing fiscal space to support agriculture. As noted by many observers, the share of government expenditure devoted to agriculture is generally low in Africa (Benin and Yu 2013; IFPRI 2015; AGRA 2016; Goyal and Nash 2016; Mukasa 2018). Typically, the higher the deficit in the government budget, the lower the share of government expenditure devoted to the development of agriculture (see Figure 12.10). Hence, rising debt and increased debt service generally lead to limited fiscal space for many governments, often forcing them to reduce spending on agriculture-related programs.

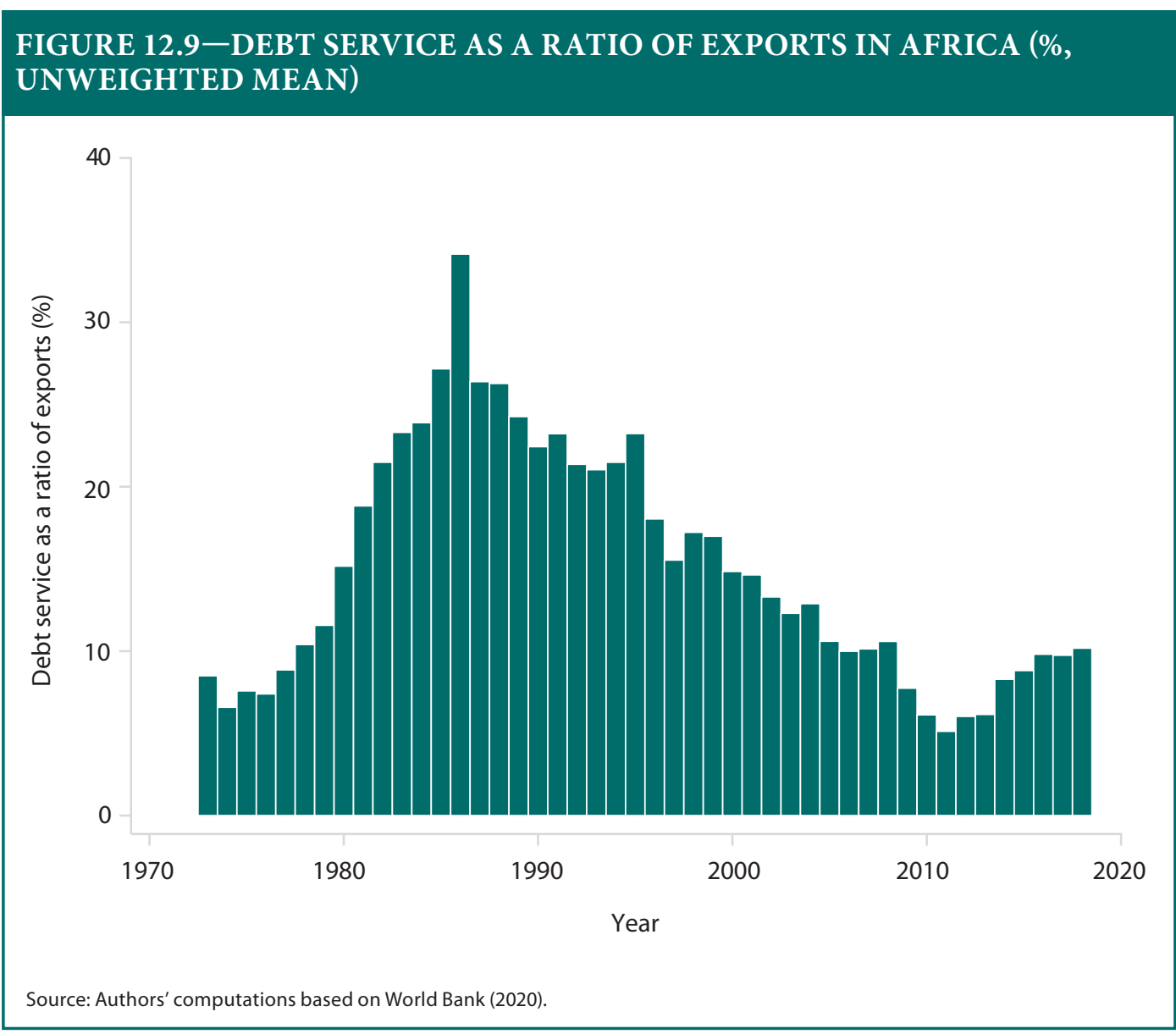

Most importantly, there is a significant and negative correlation between external debt and agricultural productivity in Africa (see Figure 12.11). This correlation may suggest various relationships between debt and the performance of the agricultural sector. One possibility is that in countries where agriculture is growing slowly or productivity is low, there is more opportunity to resort to borrowing for consumption smoothing at the national level, prompting higher debt. Thus, weak or low growth in the agricultural sector could be a source of increased borrowing. The other possibility is that 
FIGURE 12.10-SHARE OF GOVERNMENT EXPENDITURE ON AGRICULTURE AND BUDGET BALANCE IN SELECTED AFRICAN COUNTRIES

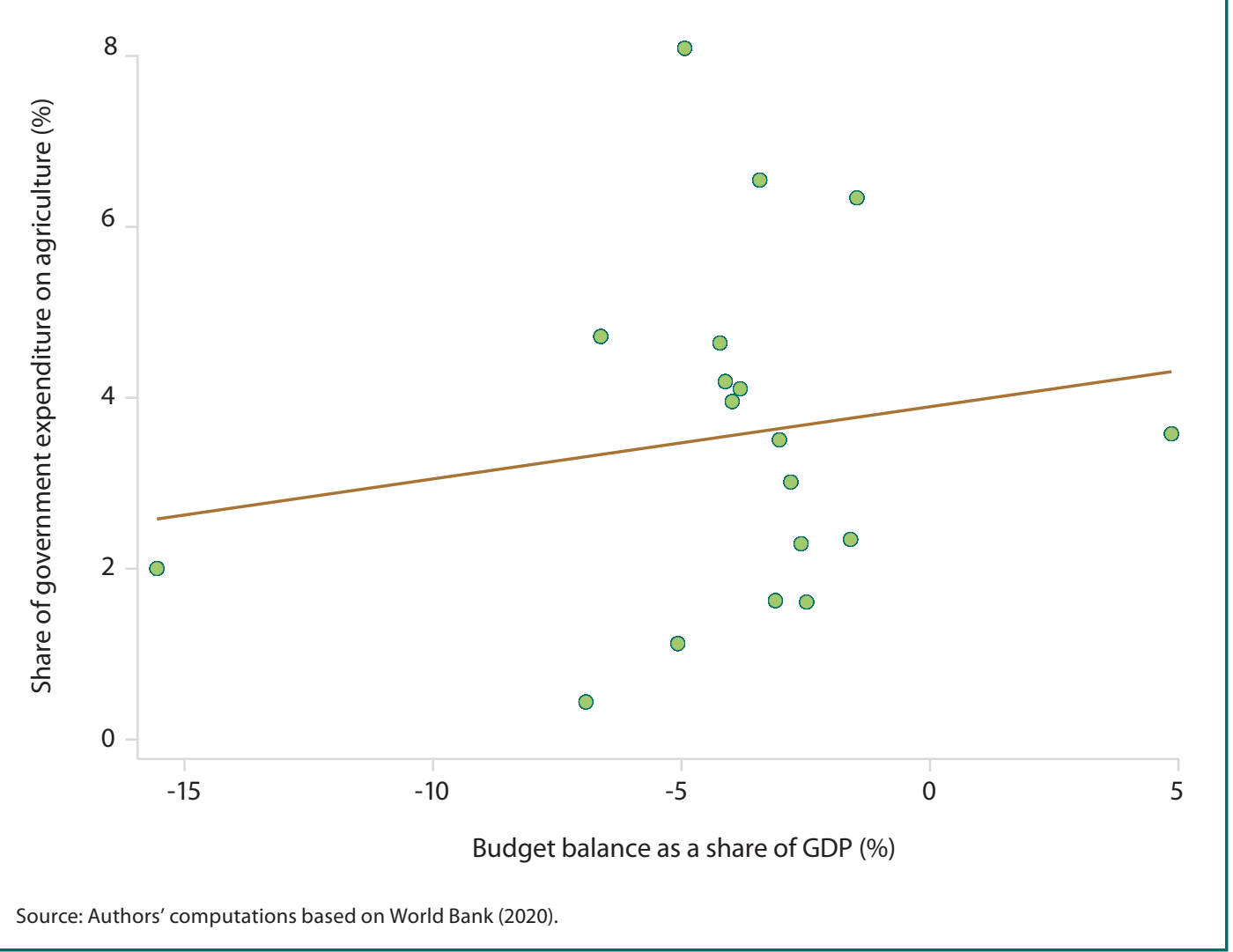

countries that tend to accumulate external debt seem to invest in urban-biased infrastructure and other projects that directly or indirectly undermine the performance of agriculture. Whatever the case, we were able to document the persistence of negative and significant relationships between various indicators of performance of the agricultural sector, such as growth in the real value added of agriculture; growth in value added per worker regressed on debt and other control variables, including time and country fixed effects; misalignment of exchange rates; terms-of-trade shocks; government primary balance; and so on. In this analysis, we found that a 1 percent increase in external debt was associated with a 0.45 percent decrease in the growth of real agriculture value added.
However, more granular research is needed to establish real causal relationships.

\section{Conclusions and Policy Recommendations}

This chapter has emphasized the need for a sound and stable macroeconomic environment for any agricultural sector policy to succeed. Such success can be measured in terms of the attainment of the diverse national and regional goals of enhancing productivity and efficiency, improving food security, reducing poverty and inequality, boosting employment, earning foreign exchange, promoting the desired industrialization, achieving sustainable agriculture based on capacity for climate change risk mitigation, and attaining general economic development. Nearly all countries in Africa have seen marked improvement in their macroeconomic environments, sustained by the unprecedented economic growth they have experienced over the past two decades.

Nevertheless, there is scope for improvement in macroeconomic policy, in particular in agricultural-sector-specific policies and the indirectly linked policies that work in concert to make agriculture more efficient, productive, and inclusively beneficial to smallholder producers. One of the missing links is market development in the agricultural sector. The market is the most efficient instrument to distribute the economic rents being generated by the agricultural sector. Downstream, farmers must know there is a market for their surplus, which will signal productivity improvements; upstream, uptake in the market and efficient transportation, postharvest management, processing, and storage as well as food security should be addressed by a comprehensive policy and institutional infrastructure that directly links to a macroeconomic policy regime.

While other macroeconomic policy aspects remain very important for the development of the African agricultural sector, fiscal policy stands out as one of the most critical aspects of the current and future policy environment, given a majority of African countries' overwhelming endorsement of the CAADP 


\section{FIGURE 12.11-EXTERNAL DEBT AND AGRICULTURAL VALUE ADDED PER} WORKER IN AFRICA

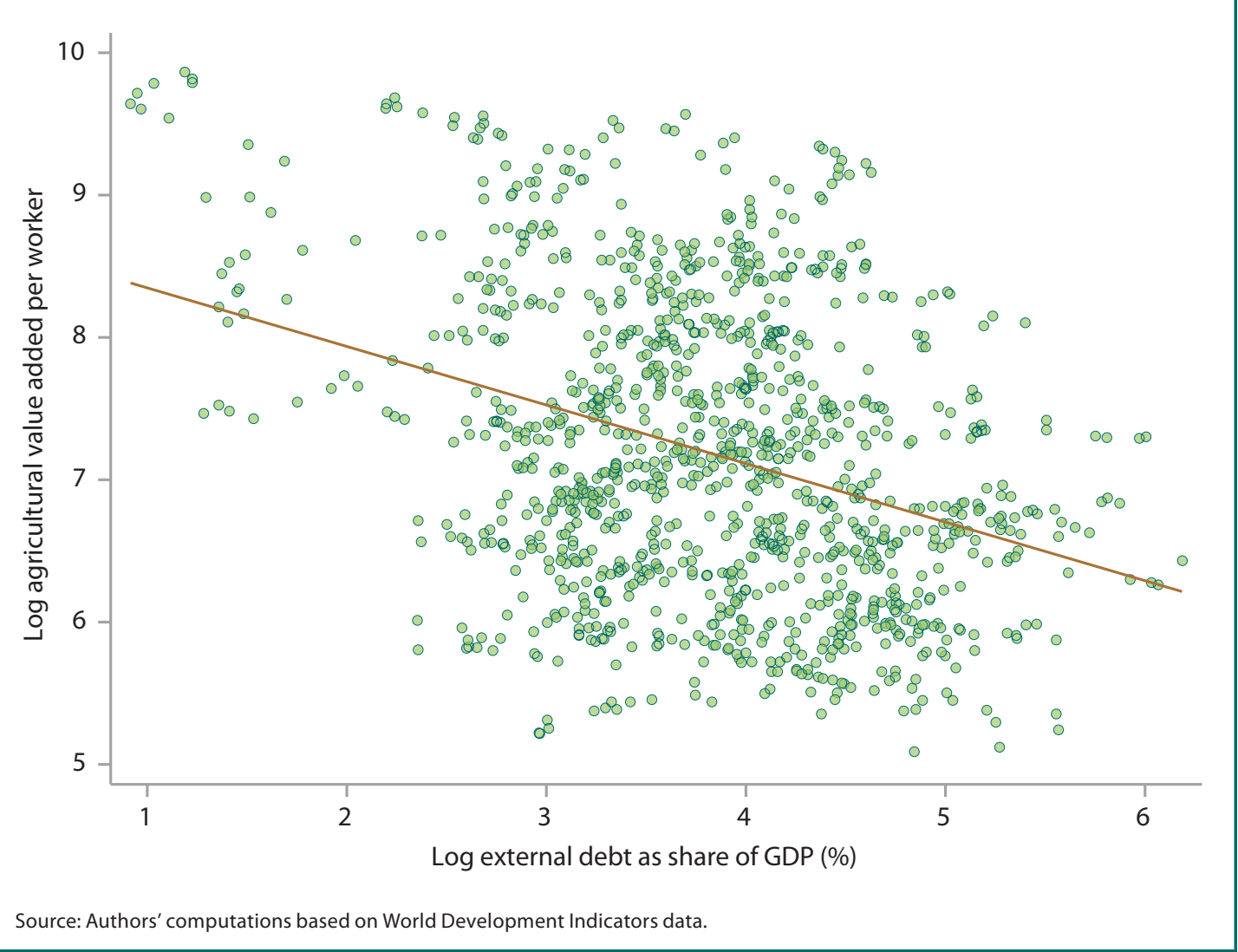

framework targeting expenditure of at least 10 percent of annual public budgets on agriculture. The important question of optimal allocation of resources in the agricultural sector remains. Evidence from the experience of other agriculturally successful countries points to the need for sustained spending to improve and maintain infrastructure such as roads, agricultural facilities, rural markets, and irrigation systems to help the continent bridge its infrastructure gap, but above all a system for buying surplus from smallholder farmers that also includes processing and storage.
Equally, sustained investment in agricultural R\&D and extension work is positively correlated with increases in productivity, innovation, and the use of new technologies, as demonstrated by the case of Brazil and other agriculturally successful countries (Evenson and Golli 2003). Research shows that agricultural $\mathrm{R} \& \mathrm{D}$ posts far higher returns on investment than investment in fertilizers, machinery, human resource training, and land quality (Evenson and Golli 2003; Thirtle, Lin, and Piesse 2003). However, efforts and investments in $R \& D$ require long time horizons to yield results, so sustained investment from the public sector is required. Over the past decades, growth in spending on agricultural R\&D has been slower than growth in spending on other forms of investment in agriculture. This is due to low government funding and ad hoc funding by external sources, mainly donor funds. Volatility in R\&D spending is counterproductive and wasteful because the interruptions and inconsistencies in spending act to cancel out any potential long-term yields. Therefore, a well-informed agricultural R\&D policy commitment is needed. On the brighter side, there has been a small increase in agricultural R\&D spending since African countries committed themselves to the CAADP framework.

Public policy attention must also be directed at formulating the fine details of pragmatic pro-export / open trade policies targeted at removing the constraints to intra-African trade in agricultural commodities, including tariff and nontariff barriers due to highly regionalized trade policies, and poor transportation networks that impede and raise the cost of access to markets. Because of the dependence on natural agroecological factors and rainfed agriculture, there is enormous but latent potential for differentiation in agricultural production beyond what is dictated by the current factors within the continent. Therefore, raising productivity is in itself a requisite condition for successful intra-African trade in agricultural commodities.

Needless to say, public programs to help the small-scale farmers who make up the majority of African farmers are critical to improving productivity and 
steering African agriculture from traditional to business-oriented farming. Therefore, public policy must address the use of subsidies and other support systems using public money. Whereas subsidies on fertilizers could be used to increase the use of fertilizers to improve productivity, this is not viable in the long term. Prolonged use of subsidies will only undermine the prospects of developing functional input markets. Likewise, output price support systems need to be market friendly, as even small-scale farmers are quite responsive to market-oriented incentives. Extension work and training programs for farmers are perhaps one of the most viable and sustainable means of helping smallscale farmers learn about better inputs and how to interact with agricultural markets. In this regard, incentives such as relief from taxes on product sales to encourage smallholder farmers to join farmers' organizations can help in dealing with a number of demand- and supply-side constraints, as in the case of Malawi's exemption of smallholder tobacco farmers affiliated with the National Smallholder Farmers' Association of Malawi (Chirwa 2009). It is notable that the positive externalities generated from farmers' membership in smallholder farmers' organizations may well outstrip any benefits of tax revenues to government coffers.

Attention must also be directed to proper agricultural policy sequencingfor instance, providing irrigation facilities may be a catalyst for the adoption of new farming methods and the use of inputs that drive up productivity. Therefore, the first emphasis and priority in spending should be on irrigation infrastructure, complemented by other facilities, rural markets, roads, and extension work. Likewise, sustained high levels of investment in R\&D must come first, as the outcomes lead to or act as a catalyst for the other goals requiring public attention in the agricultural sector. A significant portion of the funding for these first-stage policy priorities may need to come from national public coffers to avoid the volatility associated with external sources of financial resources.

Although the macroeconomic policy environment and specific policies for the agricultural sector have improved in African countries, much room remains for further policy improvement. The focus of such improvement should be on more pragmatic, market-oriented, and sustainable policies that can be effective in meeting the countries' efficiency, equity, and food security goals. Public support systems for small commercial farmers need not crowd out private sector initiatives and input market development. Emphasis must be placed on fiscal policy, with the key concern being efficacy of spending in the agricultural sector. In that regard, policy should focus on increasing spending on R\&D, agricultural extension work, and providing irrigation systems and other agricultural infrastructure. These efforts must involve sustained investment to avoid the current volatility in the funding of $R \& D$ in African agriculture. 